\title{
VALENCY POTENTIAL OF SLOVAK AND FRENCH VERBS IN CONTRAST
}

\author{
KATARÍNA CHOVANCOVÁ - LUCIA RÁČKOVÁ - \\ DAGMAR VESELÁ - MONIKA ZÁZRIVCOVÁ
}

The Faculty of Arts, Matej Bel University in Banská Bystrica, Slovakia

\begin{abstract}
CHOVANCOVÁ, Katarína - RAČKOVÁ, Lucia - VESELÁ, Dagmar ZÁZRIVCOVÁ, Monika: Valency Potential of Slovak and French Verbs in Contrast. Journal of Linguistics, 2017, Vol. 68, No 2, pp. 156 - 168.
\end{abstract}

\begin{abstract}
The paper presents results of synchronous contrastive study of fifteen most frequent Slovak full verbs and their French equivalents by the method of corpus analysis aimed at observation and comparison of their valency potential in relation to their semantic structure. The inventory of valency structures of Slovak verbs and their French equivalents shows not only differences, but also, to a great extent, identical semantic-syntactic connectivities. The main apport of the study lies in the contrastive research perspective and the interdisciplinary character on the crossroads of grammar, semantics, syntax, cognitive and corpus linguistics. Findings can be of use to linguists, terminologists, lexicographers, authors of textbooks and grammars, translators and interpreters, as well as to Frenchspeaking learners of Slovak and Slovak students of French.
\end{abstract}

Keywords: linguistics, grammar, corpus, verb, valency

\section{INTRODUCTION}

The paper arises from contrastive research of valency of Slovak and French verbs carried out at Matej Bel University in Banská Bystrica in cooperation with the Ludovít Štúr Institute of Linguistics of the Slovak Academy of Sciences within the research grant project VEGA - Valenčné potencie slovies $v$ kontraste/Valency Potential of Verbs in Contrast (2014-2016). It sums up research objectives, methodology and results. It points out at specificities of contrastive analysis of valency structures of Slovak and French verbs and presents partial conclusions.

The research was based on the premises of general and contrastive linguistics. It focused on the verb as a crucial point of syntax and, specifically, on valency as one of its distinctive features. In linguistics, as well as in methodology of teaching foreign languages, verb valency has frequently been researched on. A contrastive linguistic approach linked to computer-based treatment of language is less frequent, still very enriching.

\section{RESEARCH ON VALENCY POTENTIAL OF SLOVAK AND FRENCH VERBS IN CONTRAST}

The research was centered on a synchronous contrastive study of valency and semantic structures of fifteen most frequent Slovak full verbs (according to the 
frequency list generated from the monolingual corpus sme2011, a part of written corpora of the Slovak National Corpus) and their French equivalents in order to investigate and compare their valency potential in relation to their semantic structure in Slovak and French language. Among selected Slovak verbs, the following full polysemic units appeared (listed from the most frequent, with most frequent English equivalents): povedat' (to tell), hovorit' (to speak), dostat' (to get), tvrdit' (to affirm), prist' (to arrive), hrat' (to play), ziskat' (to get, to obtain), platit' (to pay), mysliet' (to think), rozhodnút' (to decide), vidiet' (to see), stát' (to stand), čakat' (to wait), nájst' (to find), patrit' (to belong). All of these units are treated as independent head words in Ivanová et al. (2014). The verb hovorit' (to speak) stands together with its aspectual pair word povedat' (to tell) in one entry, then it stands alone in a separate entry, as well. This treatment is identical to the one presented in [3].

Leaning on already existing inventory of possible valency structures of Slovak full verbs we constructed an inventory of valency structures of French equivalents of different meanings of these Slovak verbs in form of bilingual dictionary entries. Meanings of verbs are the part of cognitive systems of two typologically different languages: Slovak, predominantly fusional language, and French, an analytic one. Despite this difference, the languages show not only differences, but also identical syntactic and semantic connectivities.

Original verbal lexemes are taken from [3]. We share the concept of valency adopted by its authors, defined as the capacity of the verb to control a certain number of arguments, determining their formal and semantic features.

Identification of French equivalents of various meanings of Slovak polysemic verbs and contrastive-comparative analysis of valency structures in both languages have been part of our research. The contrastive study was based on several Slovak and French theoretical works, among others [8], [11] and [12]. Among French sources, there are [13], [1] and [7].

The inventory of valency structures of Slovak full verbs and their French equivalents and description of their valency properties with regard to identical, partially identical and different semantic and syntactic features in Slovak and French was based on specialized corpora sme2011 and LeMonde0.3.

Sme2011 is a specialized monolingual written corpus containing press articles published in SME, the Slovak National daily newspaper, from January 1 to December 31,2011 . It was created as a selection of texts contained in prim-6.1.public-all, main part of the Slovak National Corpus. It contains 6516876 text units (tokens), out of which 5 409453 word forms. The corpus, consisting in 409509 sentences, is fully lemmatized and morphologically annotated. The automatic morphological annotation was done by Morče tool based on the morphological tagset used in the Slovak National Corpus.

Le Monde 0.3 is a specialized foreign-language written corpus containing press articles from Le Monde, French national daily newspaper, published from January 1 to December 31, 2011. It contains 21969159 text units (tokens) and consists of 829092 sentence structures. It is fully lemmatized and morphologically annotated. The automatic morphological annotation was done by TreeTagger and it uses a free set of morphological tags for French language. Sme2011 and LeMonde0.3 can be browsed using NoSketch Engine tool of the Slovak National Corpus. 
Research results were published as a bilingual dictionary of valency structures of Slovak and French verbs [14]. The publication is primarily destinated to students of French philology and translation studies, as well as scholars dealing with comparison of Slavic and Romance languages and with corpus linguistics.

\section{EXAMPLE OF CONTRASTIVE PRESENTATION OF SLOVAK AND FRENCH VALENCY STRUCTURES}

The basic entry unit of the dictionary Valenčné potencie slovies $v$ kontraste [14] is represented by a Slovak full polysemic verb with specific aspectual characteristics whose semantic structure consists in 1 to $\mathrm{n}$ partial meanings (verbal lexemes). Idiomatic meanings, as defined in [3], were excluded. For each meaning, one or more semantically equivalent French lexical units are given. The structure of the bilingual dictionary entry has two parts - the Slovak one (starting point for comparison) and the French one. The Slovak part of the bilingual entry contains:

a) Slovak full verb to be analyzed,

b) partial meaning of the Slovak full verb no. 1 to $n$,

c) valency structure of the Slovak verb in form of a valency pattern,

d) a morphological-syntactic characteristic of left and right arguments appearing in the valency pattern and semantic roles of arguments of the verbal lexeme,

e) synonyms of the Slovak verbal lexeme,

f) description of the meaning of the Slovak verbal lexeme no. 1 to n,

g) examples of use of the valency structure of the Slovak verb taken from sme2011.

Points b) to f) are taken from [3].

The French part of the bilingual entry contains:

a) the French equivalent of the Slovak verbal lexeme no. 1 to n,

b) valency structure of the French equivalent,

c) description of the meaning of the French lexical unit semantically equivalent to the Slovak verbal lexeme (based on French monolingual dictionaries),

d) examples of use of the valency structure of French lexical units equivalent to Slovak verbal lexeme, taken from Le Monde 0.3.

In all, 20 bilingual entries were analyzed.

To give an example of the contrastive approach, we present the analysis of the second meaning of the polysemic verb patrit' (to belong) and its French equivalents. According to [3], monoaspectual imperfective verb patrit' ndk (to belong as an imperfective verb) is formed of five independent verbal lexemes (five meanings); four of them (non idiomatic ones) are treated in the dictionary. The partitive meaning patrit' 2 "byt' členom, súčast'ou niečoho" (to be part of something), is given below as an example of contrastive presentation of valency structures. This meaning can be expressed, in French, by two different lexemes, both of them semantically equivalent: appartenir (to belong) "faire partie organique d'un ensemble" (to be an organic part of a whole) and rentrer (to fit) "faire partie de, être contenu, inclus dans une classe, une catégorie" (to be a part of something, to be contained in something, to be included in 
a class or a category). The first equivalent, appartenir, requires a right-side argument fulfilling the syntactical role of indirect object, introduced by the only possible preposition $\dot{a}$. The argument can be expressed by a subordinate clause introduced by à ce que (Slovak valency structure being expressed as $\mathbf{V S}_{\mathbf{s l o}}: \mathbf{S}_{\mathbf{n}}-\mathbf{V F}-\mathbf{k} \mathbf{S}_{\mathbf{d}} / \mathbf{m e d z i}$ $\mathbf{S}_{\mathbf{a}}$, the corresponding French valency structure being expressed as $\mathbf{V S}_{\mathbf{f r a}}: \mathbf{S}_{\mathbf{S}}-\mathbf{V F}-$ à $\mathbf{S}_{\mathbf{C O I}} / \mathbf{P S}_{\mathbf{a}}$ ce que). In the valency structure of the intransitive verb rentrer, with a broader meaning than appartenir, the right side of the valency structure is reduced the indirect object is not a part of it anymore. The obligatory right-side argument is, in this case, the adverbial of direction $\mathbf{V S}_{\mathbf{f r a}}: \mathbf{S}_{\mathbf{S}}-\mathbf{V F}-\mathbf{A D V}$ dir3.

\section{VL/SLO/2: patrit'}

$V \breve{S}_{\text {slo }}: S_{\mathbf{n}}-V F-k S_{d} /$ medzi $S_{a}$

$\mathbf{S}_{\mathbf{n}}:[\mathrm{BO}] \mathrm{STAT}_{\text {part }}$

k $\mathbf{S}_{\mathbf{d}} / \mathbf{m e d z i} \mathbf{S}_{\mathbf{a}}:[\mathrm{BO}]$ TOTUM

SYN/SLO/VSSSKZ: zarad'ovat' $\mathrm{sa}^{1}$

\section{DEF/VL/SLO/2: byt' členom, súčast'ou niečoho²}

\section{EXSLO/SME2011:}

1. Majster gotických malieb z Okoličného patril k najlepším maliarom stredoeurópskej neskorej gotiky ${ }^{3}$. (SME 2011-01-04)

2. K jeho obl'úbenej literatúre patrí Starec a more ${ }^{4}$. (SME 2011-01-10)

3. Artefakt starý 3400 rokov patrí medzi najznámejšie staroveké pamiatky 5 . (SME 2011-01-25)

$\rightarrow$ EKV/FRA/VL/SLO/2: appartenir

$V \check{S}_{\text {fra }}: S_{S}-V F-$ à $S_{C O I} / P_{\text {à ce que }}$

\section{DEF/FRA/TLF: faire partie organique d'un ensemble ${ }^{6}$}

\section{EXFRA/LEMONDE0.3:}

1. Né en 1786, il appartient à une génération qui se détourne de la vogue du premier romantisme noir ${ }^{7}$. (Le Monde, 4 avril 2011)

\footnotetext{
${ }^{1}$ To range among something.

${ }^{2}$ To be a member, a part of something,

${ }^{3}$ The master of Gothic painting from Okoličné ranged among the best artists of late Gothic period in the Central Europe.

${ }^{4}$ The Old Man and the Sea ranged among his favourite books.

${ }^{5}$ A 3400-year-old artifact ranges among the most famous Ancient relics.

${ }^{6}$ To be a organic part of a whole.

${ }^{7}$ Born in 1786 , he belongs to a generation which rejects the wave of the first romanticism noir.
} 
2. Née le 20 octobre 1928 à Caudéran, Hélène Surgère appartenait à la bourgeoisie, qu'elle a fuie ${ }^{8}$. (Le Monde, $1^{\mathrm{er}}$ avril 2011)

3. Ainsi, l'on apprend que les poufs animaliers appartiennent à ce que les deux artistes appellent avec tendresse le « design de compagnie $»^{9}$. (Le Monde, 24 janvier 2011)

\section{$\rightarrow \mathrm{EKV} / \mathrm{FRA} / \mathrm{VL} / \mathrm{SLO} / 2:$ rentrer}

$$
V_{S_{f r a}}: S_{S}-V F-A D V_{d i r 3}
$$

DEF/FRA/CNRTL: faire partie de, être contenu, inclus dans une classe, une catégorie $^{10}$

\section{EXFRA/LEMONDE0.3:}

1. Pour montrer sa bonne volonté, la BCE, elle, continuera d'accepter que les banques à qui elle prête de l'argent lui apportent en garantie de la dette portugaise, malgré le fait que celle-ci ne rentre plus dans les critères acceptés par l'institut monétaire ${ }^{11}$. (Le Monde, 11 juillet 2011)

2. Les grandes croix rentrent dans le trésor de la tradition, lequel est patrimoine national et n'a pas d'étiquette sociale ${ }^{12}$. (Le Monde, 15 juillet 2011)

3. Or je ne pense pas que faire décoller tous les avions rentre dans ces conditions $^{13}$. (Le Monde, 24 décembre 2011)

The following table contains an overview of valency patterns corresponding to all meanings of the verb patrit' (belong) and its French equivalents.

\begin{tabular}{|l|l|l|l|l|}
\hline No. & VŠslo & VŠfra & EKV/FRA & $\begin{array}{l}\text { Degree of } \\
\text { equivalence }\end{array}$ \\
\hline $\begin{array}{l}\text { VL/SLO/1 } \\
\text { byt' vlastníctvom } \\
\text { niekoho, prislúchat' } \\
\text { (to be a property of } \\
\text { someone, to belong } \\
\text { to someone) }\end{array}$ & $\mathrm{S}_{\mathrm{n}}-\mathrm{VF}-\mathrm{S}_{\mathrm{d}}$ & $\mathrm{S}_{\mathrm{S}}-\mathrm{VF}-\mathrm{à} \mathrm{S}_{\mathrm{COI}}$ & $\begin{array}{l}\text { appartenir } \\
\text { (to belong) }\end{array}$ & 1 \\
\hline
\end{tabular}

\footnotetext{
${ }^{8}$ Born on $20^{\text {th }}$ October 1928 in Caudéran, Hélène Surgère belonged to the bourgeoisie that she flew from.

${ }^{9}$ Thus, we learn that the poufs with animal patterns belonged to what the two artists gently called « company design ».

${ }^{10}$ To be a part of something, to be contained in something, to be included in a class or a category.

${ }^{11}$ To show its good intentions, the CEB will continue to accept that the banks to which it lends money bring as a guarantee a part of the Portuguese debt, despite the fact it does not fit the criteria accepted by the monetary financial institution.

${ }^{12}$ Big crosses belong to the treasure of tradition, which is national heritage and does not bear a social label.

${ }^{13}$ I don't think that making all the planes take off fits the conditions.
} 


\begin{tabular}{|c|c|c|c|c|}
\hline \multirow[t]{2}{*}{$\begin{array}{l}\text { VL/SLO/2 } \\
\text { byt' členom, } \\
\text { súčast'ou niečoho (to } \\
\text { be a member, a part } \\
\text { of something) }\end{array}$} & $\begin{array}{l}\mathrm{S}_{\mathrm{n}}-\mathrm{VF}-\mathrm{kS}_{\mathrm{d}} / \\
\text { medzi } \mathrm{S}_{\mathrm{a}}\end{array}$ & $\begin{array}{l}\mathrm{S}_{\mathrm{S}}-\mathrm{VF}-\text { à } \mathrm{S}_{\mathrm{COI}} / \mathrm{PS}_{\text {à }} \\
\text { ce que }\end{array}$ & $\begin{array}{l}\text { appartenir } \\
\text { (to belong) }\end{array}$ & 3 \\
\hline & & $\mathrm{S}_{\mathrm{S}}-\mathrm{VF}-\mathrm{ADV}_{\operatorname{dir} 3}$ & $\begin{array}{l}\text { rentrer (to } \\
\text { fit) }\end{array}$ & 3 \\
\hline \multirow{2}{*}{$\begin{array}{l}\text { VL/SLO/3 } \\
\text { mat' niekde náležité } \\
\text { miesto (to have } \\
\text { one's proper place) }\end{array}$} & $\begin{array}{l}S_{n}-V F- \\
A D V_{\operatorname{dir} 3}\end{array}$ & $\mathrm{~S}_{\mathrm{S}}-\mathrm{VF}-\mathrm{ADV}_{\operatorname{dir} 3}$ & $\begin{array}{l}\text { appartenir } \\
\text { (to belong) }\end{array}$ & 1 \\
\hline & & $\begin{array}{l}\mathrm{S}_{\mathrm{S}}-\left[\mathrm{VF}_{\text {avoir/ }}\right. \\
\text { trouver } \\
\mathrm{ADV}_{\mathrm{loc}}\end{array}$ & $\begin{array}{l}\text { avoir / } \\
\text { trouver sa } \\
\text { place (to } \\
\text { have/to find } \\
\text { its place) } \\
\end{array}$ & $\begin{array}{l}3 \text { ( }+ \text { change } \\
\text { in the formal } \\
\text { expression of } \\
\text { the predicate) }\end{array}$ \\
\hline $\begin{array}{l}\text { VL/SLO/4 } \\
\text { byt' určený, týkat' } \\
\text { sa niečoho (to } \\
\text { be destinated to } \\
\text { something, to } \\
\text { concern something) }\end{array}$ & $\begin{array}{l}\mathrm{S}_{\mathrm{n}}-\mathrm{VF}-\mathrm{S}_{\mathrm{d}^{-}} \\
\mathrm{ADV} \mathrm{V}_{\mathrm{kauz}}\end{array}$ & $\begin{array}{l}\mathrm{S}_{\mathrm{S}}-\mathrm{VF}-\mathrm{à}_{\mathrm{COI}^{-}} \\
\mathrm{ADV} \mathrm{V}_{\text {kauz }}\end{array}$ & $\begin{array}{l}\text { revenir (to } \\
\text { relate to, to } \\
\text { go back to) }\end{array}$ & 1 \\
\hline
\end{tabular}

Tab. 1. Valency structures of patrit' and its French equivalents

\section{ASSESSING EQUIVALENCE OF VALENCY STRUCTURES}

The contrastive analysis of valency structures of Slovak and French verbs lets us asses the degree of equivalence of valency patterns of verbal lexemes in both languages. The equivalence is understood as a variable, expressing a functional correspondence of compared elements. Its value can be scaled from "zero" through "partial" to "total".

When assessing equivalence of valency structures of verbs, it is necessary to take into consideration two aspects. The first of them is a potential ambivalence of the relation between the formal expression of relationships within the valency structure of the verb and the functional value of its arguments. In some cases, valency structures can contain functionally equivalent elements having different formal means of expression. This results from different typological features of Slovak and French, mainly from the existence of nominal flexion in Slovak and its corresponding expression by analytical structures in French. Therefore, while evaluating valency structures, syntactical function of valency arguments will be considered binding. Thus, Slovak valency pattern $\mathbf{S}_{\mathbf{n}}-\mathbf{V F}-\mathbf{S}_{\mathbf{d}}$ and French valency pattern $\mathbf{S}_{\mathbf{S}}-\mathbf{V F}-$ à $\mathbf{S}_{\mathbf{C O I}}$ will be seen as equivalent.

Another factor influencing contrastive assessment of Slovak and French valency structures is the potential character of some arguments. If some arguments in Slovak valency pattern are potential and the corresponding (functionally equivalent) arguments in the French valency structure are obligatory or vice versa, we define the degree of equivalence of these valency structures as partial. Thus, the 
pair of valency structures $\mathbf{S}_{\mathbf{n}}-\mathbf{V F}-\mathbf{S}_{\mathbf{a}}$ in Slovak and $\mathbf{S}_{\mathbf{S}}-\mathbf{V F}-\left(\mathbf{S}_{\mathbf{C O D}}\right)$ in French is seen as partially equivalent.

The comparison concerns primary, non-transformed valency structures of analyzed verbs. Contrastive assessment of transformed structures would be highly limited by systemic non-correspondence of their formal expression. This is the case of character and position of reflexive structures in French and Slovak, as well as systematics and semantics of impersonal verb forms entering active or passive structures. These specific questions require special attention.

In total, 165 pairs of valency patterns were compared. In some cases, only one French valency pattern corresponded to the original Slovak valency pattern related to a particular meaning of the Slovak verb. Elsewhere, a multilateral correspondence was observed: several valency patterns of one or more French verbs could be paired with the original Slovak valency pattern. Thus, the total number of pairs of valency patterns does not reflect the actual number of semantic equivalences between Slovak verbs and their French equivalents. For instance, the analysis of the Slovak verb verb rozhodnút' 'decide' (finite)/rozhodovat' (non-finite) in its perfective and imperfective form) reveals the presence of 3 valency patterns corresponding to 3 different meanings of the verb. On the other hand, we identify 8 valency patterns corresponding to 19 different meanings of 5 different French verbs semantically equivalent to rozhodnút' dk/rozhodovat' ndk (décider - to decide, résoudre - to resolve, arbitrer to arbitrate, trancher - to cut, statuer - to state).

With regard to the above stated remarks, we set up following degrees of equivalence:

1 - total functional equivalence of valency and non valency components

2 - total functional equivalence of valency participants

3 - partial functional equivalence of valency participants

4 - zero functional equivalence of valency participants.

Given the predominantly obligatory character of left-side participant, the focus is on measuring the degree of functional equivalence of right-side participants.

Degree 1 indicates cases when Slovak and French valency structures contain an equal number of right-side participants and each obligatory or potential right-side participant in the Slovak valency structure finds, in the French valency structure, a corresponding participant with identical syntactic function (for instance $\mathbf{S}_{\mathbf{a}}-\mathbf{S}_{\mathbf{C O D}}$ ) and with identical obligatory or potential character. At the same time, Slovak and French valency structures contain an equal number of identical non-valency complementations.

Degree 2 is used for cases when Slovak and French valency structures contain an equal number of functionally corresponding right-side elements. These participants correspond in their syntactic function as well as in their obligatory or potential character.

Degree 3 is used for cases when:

a) Slovak and French valency structures do not contain an equal number of obligatory and/or potential participants, still there is at least one relation of functional correspondence between a right-side participant in the Slovak valency structure and a right-side participant in the French valency structure, 
b) there are differences in the obligatory and/or potential character of functionally corresponding right-side participants.

Degree 4 indicates cases when it is not possible to identify any relation of functional equivalence between a participant in the Slovak valency structure and a participant in the French valency structure.

While assessing the equivalence of structures, variability of morphological expression of valency participants is not taken into account, i.e. $\mathbf{S}_{\mathbf{a}} / \mathbf{V} \mathbf{V}_{\check{\mathbf{z}} \mathbf{e}}$ and $\mathbf{S}_{\mathbf{C O D}}$ are considered equivalent.

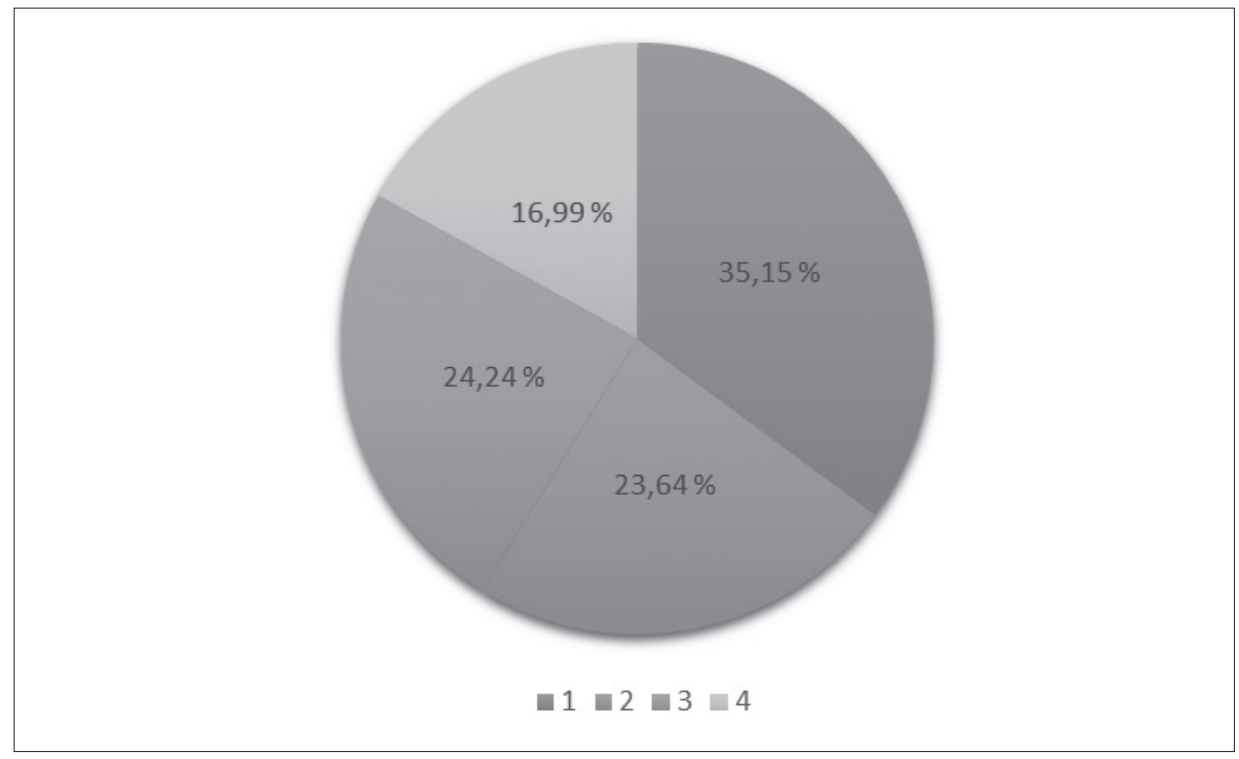

Fig. 1. Degrees of equivalence of Slovak and French verb valency structures

The proportional representation of various degrees of equivalence is shown in Figure 1. The largest group is marked as degree 1 of equivalence $(35.15 \%)$, the least numerous group is characterized by zero functional equivalence - degree $4(16.99 \%)$.

Degrees 1 and 2 have important ratios. The sizes of these groups indicate that the conventional idea about substantial differences in valency of verbs between French and Slovak - a belief which is often present in teaching/learning of French as a foreign language - does not necessarily reflect reality.

On the other hand, the cases where zero degree of equivalence (degree 4) of valency participants has been proved, may become the most important source of negative transfer in the situations of language contact in everyday communication, as well as in the process of language acquisition.

\section{DEGREES OF EQUIVALENCE OF SLOVAK AND FRENCH VALENCY STRUCTURES}

The corpus contains all 4 degrees of equivalence of valency structures of the Slovak and French verbs, illustrated as follows. 


\subsection{Total Equivalence of Valency and Non-valency Components}

Degree 1 (total functional equivalence of valency and non-valency complementations) can be seen in the derived meaning of vidiet'/uvidiet' 4 (to see) "stretat' sa s niekým, dostávat' sa do styku" (to meet someone, to get in touch with someone) and its French equivalent voir (to see) ,fréquenter quelqu'un, le rencontrer lors d'une visite, dans le cadre de relations familiales ou sociales, rencontrer quelqu'un, se trouver par hasard en sa présence“" (to see someone, to meet someone in a visit within a family of a society, to meet someone by accident):

(1) Bývam v jednom dome s Jožkom Stümpelom a Marcelom Hossom, vidíme sa takmer každý deňํ․ (SME 2011-09-23)

(2) Chaque fois que des jeunes gens se décident à aller rejoindre une manifestation, ils font leurs adieux à leurs proches comme s'ils les voyaient pour la dernière fois ${ }^{15}$. (Le Monde, 17 juin 2011)

The corresponding valency structures are the following:

$$
\begin{aligned}
& \breve{V}_{\mathbf{S}}: \mathbf{S}_{\mathbf{n}}-\mathbf{V F}-\mathbf{S}_{\mathbf{a}}-A D V_{\text {loc }}-A D V_{\text {temp }}-A D V_{\text {meas }} \\
& \mathbf{V}_{\mathbf{f r a}}: \mathbf{S}_{\mathbf{S}}-\mathbf{V F}-\mathbf{S}_{\mathbf{C O D}}-A D V_{\text {loc }}-A D V_{\text {temp }}-A D V_{\text {meas }}
\end{aligned}
$$

The assessment of the degree of equivalence was the same when valency structures contained only valency participants. This case can be illustrated by the primary meaning of ziskat'/ziskavat' 1 (to get, to obtain) "dosiahnut', nadobudnút", and its equivalent obtenir (to obtain) "parvenir à se faire accorder, à se faire donner ce que l'on veut avoir, ce que l'on demande" (to arrive to be awarded, to be given what one wants to have, what one demands) with the following valency structures: $V \breve{S}_{\mathbf{s l o}}: S_{\mathbf{n}}-V F-S_{\mathbf{a}}-\left(\operatorname{od} S_{\mathbf{g}}\right)$ and $V \breve{S}_{\mathbf{f r a}}: S_{\mathbf{S}}-V F-S_{C O D}-\left(\operatorname{de~} S_{C O I}\right)$ :

(3) Niektoré spoločnosti však získali od NASA milióny dolárov a ich stroje už do kozmu lietajú ${ }^{16}$. (SME 2011-05-10)

(4) [...] l'activisme français a été décisif pour obtenir le feu vert de l'ONU ${ }^{17}$. (Le Monde, 29 mars 2011)

An identical degree of equivalence of valency structures can be seen in the primary meaning of patrit' 1 "byt' vlastníctvom niekoho, prislúchat" and its French equivalent appartenir "être la propriété de quelqu'un ; être le droit ou le privilège de quelqu'un" with valency structures $\mathbf{V} \check{\mathbf{S}}_{\mathbf{s l o}}: \mathbf{S}_{\mathbf{n}}-\mathbf{V F}-\mathbf{S}_{\mathbf{d}}$ and $\mathbf{V} \check{\mathbf{S}}_{\mathbf{f r a}}: \mathbf{S}_{\mathbf{S}}-\mathbf{V F}-$ à $\mathrm{S}_{\mathrm{COI}}$ :

${ }^{14}$ I live in the same house as Jožko Stümpel and Marcel Hossa, we see each other almost each day.

${ }^{15}$ Every time the young people decide to go to a demonstration, they take a farewell of their closest as if they were saw them for the last time. already.

${ }^{16}$ Some societies have obtained millions dollars from NASA and their spacecraft fly to space

${ }^{17}[\ldots]$ French activism was decisive in obtaining a consent from the UN. 
(5) Budovy na predanom pozemku patria mestu a developer ich chce zadarmo. (SME 2011-01-03)

(6) Les deux hôtels appartiennent à l'homme d'affaires saoudien, le prince AlWaleed. (Le Monde, 27 janvier 2011)

In both cases, the right-side participant is an indirect object expressed, in Slovak, without a preposition. In French, the preposition is needed. The syntactic function of participants was given priority before the means of their formal expression, as the form is often inluenced by factors of linguistic typology, i. e. $\mathbf{S}_{\mathbf{d}}$ cannot have a non-prepositional French equivalent and it most likely corresponds to à $\mathbf{S}_{\mathbf{C O I}}$. The same approach was adopted elsewhere in case of differences in formal expression of components of valency structures caused by typological differences between the languages.

\subsection{Total Functional Equivalence of Valency Participants}

Degree 2 of equivalence was used to label the cases of total functional equivalence of valency participants when there is, at the same time, absence of equivalence in non-valency complementations. As an example, let us state vidiet' 2 'stat' sa schopným vidiet", corresponding to the French verb voir "percevoir les objets du monde extérieur par l'intermédiaire des organes de la vue":

(7) A v noci vidíme šest'krát lepšie ako vy! (SME 2011-03-03)

$$
\mathbf{V S}_{\text {slo }}: \mathbf{S}_{\mathbf{n}}-\mathbf{V F}-\mathrm{ADV}_{\text {temp }}-\mathrm{ADV}_{\text {meas }}
$$

(8) [...] je ne voyais déjà pas très bien de près à l'œil nu, maintenant c'est aussi de loin. (Le Monde, 10 mars 2011)

$\mathbf{V S}_{\mathbf{f r a}}: \mathbf{S}_{\mathbf{S}}-\mathbf{V F}-\mathrm{ADV}_{\text {temp }}-\mathrm{ADV}_{\text {meas }}-\mathrm{ADV}_{\text {mod }}-\mathrm{ADV}_{\text {instr }}$

Differences in the number and the character of adverbial complements can be seen in examples (7) and (8). Adverbials appear in the French valency structure $\left(\mathbf{V} \breve{S}_{\text {fra }}\right)$, however, the are missing from the Slovak one.

\subsection{Partial Functional Equivalence of Valency Participants}

Degree 3 of equivalence refers to situations when there is a difference in the obligatory or potential character of participants or when there is a functional equivalence of some of (but not all) valency participants on one or on the other side. The potentiality of valency participants indicates their possible absence in the surface structure. It means they are not necessarily realized; still, they are semantically binding and they belong among valency participants. They appear in brackets in valency patterns.

Changes in obligatory or potential character of valency participants can be observed in the verb platit'/zaplatit' 2 (to pay) "dávat' peniaze za nejakú hodnotu" (to give money for a value) and its French equivalent payer (to pay) "verser une somme d'argent, pour s'acquitter de ce qui est dû ou pour acheter quelque chose ; s'acquitter, par un versement, de ce qui est dû" (to give a sum of money to spend what is due or 
to buy something; to give out what is due). The difference consists in the position of the right-side participant with the syntactic function of direct object. Corpus data let us conclude that, in French, this participant is of potential nature.

(9) Viac l'udí bude platit' aj odvody, do vrecka budú mat' hlbšie motoristi a l'udia si budú musiet' vybrat' medzi zamestnaním a predčasnou penziou ${ }^{18}$. (SME 2011-01-03)

$\mathbf{V S}_{\mathbf{s l o}}: \mathbf{S}_{\mathbf{n}}-\mathbf{V F}-\mathbf{S}_{\mathbf{a}}-\left(\mathbf{S}_{\mathbf{d}}\right)-\mathrm{ADV}_{\text {mot }}-\mathrm{ADV}_{\text {remp }}-\mathrm{ADV}_{\text {instr }}$

(10) Il est d'autant plus important que $80 \%$ des passagers sont anglais, paient en livres, quand en face, nous réglons nos dépenses en euros ${ }^{19}$. (Le Monde, 25 janvier 2011)

$\mathbf{V S}_{\mathbf{f r a}}: \mathbf{S}_{\mathbf{S}}-\mathbf{V F}-\left(\mathbf{S}_{\mathbf{C O D}}\right)-\left(\mathbf{a} \mathbf{S}_{\mathbf{C O I}}\right)-\mathrm{ADV}_{\text {mot }}-\mathrm{ADV}_{\text {meas }}-\mathrm{ADV}_{\text {instr }}$

Partial functional equivalence can be illustrated by the Slovak verb patrit' 2 (to belong) "byt' členom, súčast'ou niečoho" (to be a member, a part of something) and its French equivalent rentrer (to go into, to fit) "faire partie de, être contenu, inclus dans une classe, une catégorie" (to be a part of something, to be contained in something, to be included in a class or a category). Rentrer is an intrasitive verb, semantically broader than the other equivalent of the same Slovak verb, appartenir (to belong) "faire partie organique d'un ensemble" (to be an organic part of something). The right side of the valency structure of rentrer is reduced: unlike in the Slovak valency structure, the indirect object is no longer present. Instead of it, we observe the presence of an obligatory adverbial expressing direction $\mathbf{A D V}$ dir3.

(11) Majster gotických malieb z Okoličného patril k najlepším maliarom stredoeurópskej neskorej gotiky ${ }^{20}$. (SME 2011-01-04)

$V \breve{S}_{\text {slo }}: S_{\mathbf{n}}-V F-k S_{d} /$ medzi $S_{a}$

(12) Or je ne pense pas que faire décoller tous les avions rentre dans ces conditions $^{21}$. (Le Monde, 24 décembre 2011)

$\mathbf{V S}_{\text {fra }}: \mathrm{S}_{\mathrm{S}}-\mathrm{VF}-\mathbf{A D V}$ dir3

Functional equivalence of left-side participants is preserved.

\subsection{Zero Functional Equivalence of Valency Participants}

Degree 4 of equivalence relates to cases which do not fit any of the degrees described above, i. e. it is not possible to identify any relation of equivalence between rightside participants in Slovak and French valency structures. The Slovak verb čakat' (to

${ }^{18}$ More people will pay fund contributions, it will become more difficult for car owners and people will have to choose between work and early retirement.

${ }^{19} \mathrm{It}$ is important that $80 \%$ passengers are English and pay in pounds and, on the opposite corner, we pay our expenses in euro.

${ }^{20}$ The master of Gothic painting from Okoličné ranged among the best artists of late Gothic period in the Central Europe

${ }^{21}$ I don't think that making all the planes take off fits the conditions. 
wait, to expect) expressing the meaning "predpokladat' (často nepríjemnú) udalost"” (to await that something (unpleasant) happens) is an example. The Slovak valency

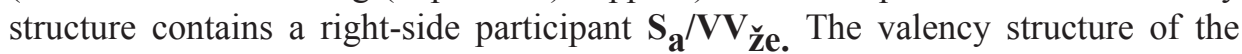
French equivalent $s$ 'attendre (to expect) contains a right-side participant of a different kind, preceded by the preposition $\grave{a}$. This preposition introduces an indirect object in the dative case à $\mathbf{S}_{\mathbf{C O I}} / \mathbf{P S}_{\mathbf{a ̀ ~}}$ ce que $\mathrm{e}^{/ \mathbf{a ̀}} \mathbf{I N F}$ :

(13) Brusel čaká, že naša ekonomika porastie na budúci rok o 1,1 percenta a česká o 0,7 percenta $^{22}$. (SME 2011-11-11)

$\mathbf{V S}_{\mathbf{s l o}}: \mathbf{S}_{\mathbf{n}}-\mathbf{V F}-\mathbf{S}_{\mathbf{a}} / \mathbf{V V} \mathbf{z ̌ \mathbf { z }}$

(14) Le groupe américain Blackrock, qui a réalisé cette étude pour le compte de l'institut d'émission, $s$ 'attend à l'aggravation des pertes bancaires entre 2011 et 2013, sous l'effet conjugué de la politique d'austérité, des faillites de PME et du trou noir représenté par les prêts aux promoteurs immobiliers ${ }^{23}$. (Le Monde, 2011-04-02)

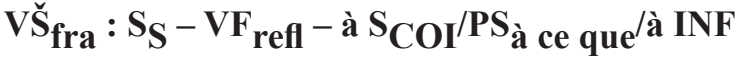

Moreover, a difference in the expression of the predicate can be observed. The French valency structure, unlike the Slovak one, contains a reflexive verb.

\section{CONCLUSION}

The research presented has been primarily inspired, on the one hand, by our efforts to formulate a new conception of contextualized grammar of the Slovak language for the French-speaking public. On the other hand, it is connected with the study of interference phenomena between French as a source language (mother tongue) and Slovak as a target language (acquired language) which has shown a potential difficulty in acquiring valency structures, as possible sources of negative transfer.

Presented results prove that differences between valency structures in both analyzed languages concern only a certain part of the ensemble of valency structures. At the same time, it has been confirmed that there is a large number of valency structures demonstrating, in a contrastive perspective, a high degree of functional equivalence. When conceiving comparative-contrastive descriptions of grammatical systems, as well as in the process of didactic mediation and facilitation of language acquisition, it is desirable not to present valency of verbs as a necessarily problematic phenomenon, but to focus the attention on structures where differences are actually observed. We believe that a contrastive overview of valency structures of the Slovak and French verbs, as it is presented in our works, can be of good use when trying to accomplish this objective.

${ }^{22}$ Brussels expects our economy to grow by 1.1 percent and Czech economy by 0.7 percent next year.

${ }^{23}$ The American group Blackrock, who launched this research for the emission institution, expects bank losses to get worse between 2011 and 2013 under the joint effect of an austere policy, SME bankruptcies and a blackhole represented by loans in real estate business. 


\section{References}

[1] Ducrot, O. and Schaeffer, J.-M. (1972). Nouveau dictionnaire encyclopédique des sciences du langage. Éditions du Seuil, Paris.

[2] Ivanová, M. (2006). Valencia statických slovies. Filozofická fakulta Prešovskej univerzity, Prešov.

[3] Ivanová, M., Sokolová, M., Kysel’ová, M., and Perovská, V. (2014). Valenčný slovník slovenských slovies na korpusovom základe. Filozofická fakulta Prešovskej univerzity v Prešove, Prešov.

[4] Kačala, J. (1989). Sloveso a sémantická štruktúra vety. VEDA, Bratislava.

[5] Klimová, K. (2012). Questioni di aspetto verbale: un confronto tra italiano e slovacco. Aracne Editrice, Roma.

[6] Křečková, V. (2012). Terminologie \& Linguistique: construction des ensembles terminologiques bilingues (slovaque - français). Fakulta humanitných vied, Univerzita Mateja Bela, Banská Bystrica.

[7] Neveu, F. (2011). Dictionnaire des sciences du langage. $2^{e}$ édition revue et augmentée. Armand Colin, Paris.

[8] Pauliny, E. (1943). Štruktúra slovenského slovesa. Štúdia lexikálno-sémantická. Slovenská akadémia vied a umení, Bratislava.

[9] Pognan, P. (2008). De la théorie à l'application: Vallex, une démarche exemplaire. The Prague Bulletin of Mathematical Linguistics, 89:97-106.

[10] Ráčková, L. (2016). Pragmatické aspekty slovenčiny cez prizmu jej frankofónneho používatela. Motus in verbo, $\mathrm{V}(1): 29-34$.

[11] Ružička, J. (1968). Valencia slovies a intencia slovesného deja. Jazykovedný časopis, 19(1):5056.

[12] Sokolová, M. (1993). Sémantika slovesa a slovesný rod. VEDA - Vydavatel'stvo Slovenskej akadémie vied, Bratislava.

[13] Tesnière, L. (1959). Éléments de syntaxe structurale. Klincksieck, Paris.

[14] Zázrivcová, M. et al. (2017). Valenčné potencie slovies v kontraste. Belianum, Banská Bystrica. 